\title{
BOOK REVIEW: THE CONSTITUTION OF INDEPENDENCE
}

\author{
Caroline Morris*
}

Peter C Oliver The Constitution of Independence: The Development of Constitutional Theory in Australia, Canada, and New Zealand (Oxford University Press, Oxford, 2005) (367 + xx pages).

Public law, like all law, is subject to ebbs and flows of academic interest in its various subtopics. One measure of that interest is the amount of comparative research and writing undertaken in an area. Unlike its fashionable cousins, human rights law and indigenous rights law, the domestic constitutional law of the Commonwealth has not attracted much attention from comparativists. However, recently United States academics have found comparative constitutional law to be a rich vein of information to mine. ${ }^{1}$ Peter Oliver's book, The Constitution of Independence, ${ }^{2}$ represents the latest contribution to the increasing canon in this field of inquiry.

Oliver addresses the conundrum so beloved of parliamentary sovereignty theorists seeking to understand the process of "well-behaved" (as Oliver puts it) colonial independence from the Westminster Parliament. Those "well-behaved" colonies - Australia, Canada, and New Zealand came by their constitutional independence not by self-declaration and popular affirmation by referendum, but via a process of incremental legal independence granted to them by the mother Parliament at Westminster. This incremental independence raises the Diceyan paradox and thus Oliver's central line of inquiry. If the Westminster Parliament is supreme, how can any law it makes abdicating its power to legislate for the colonial Parliament not be vulnerable to rescission at any time? If it does not make such a law but merely refrains by convention from legislating for its former colonies, what is to stop the Westminster Parliament from deciding to do away with that selfimposed restraint? In other words, are the former colonies of Britain ever truly legally independent, or is that independence illusory?

* Lecturer, School of Law, Victoria University of Wellington.

1 See for example Mark Tushnet "Weak-form Judicial Review: Its Implications for Legislatures" (2003) 1 NZJPIL 7; Stephen Gardbaum "The New Commonwealth Model of Constitutionalism" (2001) 49 Am J Comp L 707.

2 Peter C Oliver The Constitution of Independence: The Development of Constitutional Theory in Australia, Canada, and New Zealand (Oxford University Press, Oxford, 2005). 
Two possible explanations for the independence process are provided: the continuing process theory and the "self referencing" theory. The traditional Diceyan view is termed "continuing sovereignty": the Westminster Parliament had and still has the power to legislate for its subordinate Parliaments, notwithstanding any indications it may have made to the contrary in the past. As the well-known cases of Vauxhall Estates and Ellen Street Estates tell us, ${ }^{3}$ the full expression of parliamentary sovereignty means that Parliament may not interfere with a future Parliament's ability to legislate. The alternative, posited by Jennings, is that Parliament, being the author of the customary law of Parliament, may alter any of the rules relating to its own sovereignty, which includes the ability to impose manner and form requirements on itself or limit its ability to legislate for its colonies for once and for all - as exemplified by the comments in the South African case of Ndlwana $v$ Hofmeyer that "freedom once conferred [can] not be revoked". 4

Oliver also asks the accompanying question of how do we seek to understand and explain our constitutional history? What explanations were provided at the time for the process of independence? How did constitutional commentators and academics grapple with these two seemingly irreconcilable views of sovereignty and were they able to reach some resolution?

This is a book which had a great deal of potential. Ultimately, it seems to have been left unrealised. As a legal historiography, it does not always satisfactorily explain how people involved in creating that legal history (or in analysing it since) understand it. For example, in the case of New Zealand why is there no reference to the views of Geoffrey Palmer, former academic and Minister of Justice, who was the architect of so much New Zealand constitutional reform, who argues that the Constitution Act 1986 "contains nothing radical"? ${ }^{5}$ There is also no reference to the two then Department of Justice reports on constitutional reform that preceded the 1986 Act. ${ }^{6}$ Curious also is the omission of Paul McHugh's essay "The Historiography of New Zealand's Constitutional History", ${ }^{7}$ which provides some useful background into the mindset of those who shaped our constitutional history. Further investigation may well have revealed both a wider range of contemporary and subsequent attempts to understand the relationship between the parliaments in Wellington and Westminster. The New Zealand section in particular seems to suffer from an overreliance on only a few commentators and little in the way of recent commentary.

3 Vauxhall Estates v Liverpool Corporation [1932] KB 733 (Div Ct); Ellen Street Estates v Minister of Health [1934] 1 KB 590 (CA).

4 Ndlwana v Hofmeyer (1937) AD 229, 237 Stratford ACJ.

5 Geoffrey Palmer and Matthew Palmer Bridled Power (4 ed, Oxford University Press, Auckland, 2004) 7.

6 Department of Justice Reports of an Official Committee on Constitutional Reform (Wellington, 1986).

7 Paul McHugh "The Historiography of New Zealand's Constitutional History" in Philip Joseph (ed) Essays on the Constitution (Brookers Ltd, Wellington, 1995). 
As an exercise in constitutional theory, it does not prove one theory over the other, but instead suggests that there is nothing much to choose between them as a matter of logic: "there is no abstract logical reason to prefer either the continuing or the self-embracing interpretation of sovereignty. They are equally coherent." 8 Interestingly, Oliver's next comment may provide some jurisprudential structure to the choice (if one has to be made). He says, "Political reasons are often presented for preferring one or the other, but not surprisingly the arguments divide on either side of the debate." 9 The jurisprudential school of legal realism attempts to explain law as that which officials do - therefore, the law can be theorised in terms of what actually happened politically. This was an under-explored path of investigation, and one which would have tied in well with the initial references to Wade's arguments about a "disguised revolution" in his classic article "The Basis of Legal Sovereignty". ${ }^{10}$ While Oliver eventually expresses a preference for the selfembracing theory, the reader is left with the thought that the choice could have easily gone the other way, were it not for the views of officials and politicians that each nation could and did have the capacity to determine the end of its relationship with the mother Parliament.

A few other points are worth mentioning. The closing sections introduce a discussion about the relationship between the Westminster Parliament and Europe, with particular reference to the Factortame and Thoburn decisions. ${ }^{11}$ This comes unheralded, and while its relevance is clear, the treatment given to the topic is too scant to be satisfying. Given that the text is primarily an investigation of the process of Commonwealth independence, this discussion could also have been omitted without detracting from the overall focus of the book. Also introduced at the very end is the thought that full legal independence is only attained once a nation attains sovereignty in both the legislative and the judicial sense - raising the question of whether Oliver should have also considered the events and legislation leading up to each country's severing of ties with the Privy Council.

The book also suffers from some very dense prose and a number of distracting metaphors for the process of constitutional independence: the handing on of the master keys; the axeman severing the limb from the tree; and most arresting of all, the two horses of constitutional theory running side by side with the national rider switching saddles at different points in history.

I was hopeful when opening up this book, thinking that it might provide some useful insight into New Zealand's constitutional history, in particular from an outside perspective. Unfortunately, while the promise was there, much was missing in the execution.

8 Oliver, above n 2, 339

9 Oliver, above n 2, 339

10 H W R Wade "The Basis of Legal Sovereignty" [1955] CLJ 172.

11 Factortame v Secretary of State for Transport (No 2) [1991] AC 603 (HL); Thoburn v Sunderland City Council [2003] QB 151 (Div Ct). 